\title{
Cold-adapted enzymes produced by fungi from terrestrial and marine Antarctic environments
}

\begin{abstract}
Alysson Wagner Fernandes Duarte, Juliana Aparecida dos Santos, Marina Vitti Vianna, Juliana Maíra Freitas Vieira, Vitor Hugo Mallagutti, Fabio José Inforsato, Lia Costa Pinto Wentzel, Luciana Daniela Lario, Andre Rodrigues, Fernando Carlos Pagnocca, Adalberto Pessoa Junior \& Lara Durães Sette
\end{abstract}

To cite this article: Alysson Wagner Fernandes Duarte, Juliana Aparecida dos Santos, Marina Vitti Vianna, Juliana Maíra Freitas Vieira, Vitor Hugo Mallagutti, Fabio José Inforsato, Lia Costa Pinto Wentzel, Luciana Daniela Lario, Andre Rodrigues, Fernando Carlos Pagnocca, Adalberto Pessoa Junior \& Lara Durães Sette (2018) Cold-adapted enzymes produced by fungi from terrestrial and marine Antarctic environments, Critical Reviews in Biotechnology, 38:4, 600-619, DOI: $10.1080 / 07388551.2017 .1379468$

To link to this article: https://doi.org/10.1080/07388551.2017.1379468

\section{册 Published online: 11 Dec 2017.}

\section{Submit your article to this journal 단}

III Article views: 424

View Crossmark data $\nearrow$ 


\title{
Cold-adapted enzymes produced by fungi from terrestrial and marine Antarctic environments
}

\author{
Alysson Wagner Fernandes Duarte ${ }^{\mathrm{a}, \mathrm{b}}$, Juliana Aparecida dos Santos ${ }^{c}$, Marina Vitti Viannac, \\ Juliana Maíra Freitas Vieirac, Vitor Hugo Mallaguttic, Fabio José Inforsatoc ${ }^{c}$, Lia Costa Pinto Wentzelc, \\ Luciana Daniela Lario ${ }^{\mathrm{d}, \mathrm{e}}$, Andre Rodrigues ${ }^{c}$, Fernando Carlos Pagnocca ${ }^{c}$, Adalberto Pessoa Junior ${ }^{\mathrm{e}}$ and \\ Lara Durães Sette ${ }^{c}$

\begin{abstract}
a Universidade Federal de Alagoas, Campus Arapiraca, Arapiraca, Brazil; bivisão de Recursos Microbianos, Centro Pluridisciplinar de Pesquisas Químicas, Biológicas e Agrícolas, Universidade Estadual de Campinas, Paulínia, Brazil; 'Departamento de Bioquímica e Microbiologia, Universidade Estadual Paulistra (UNESP), Câmpus de Rio Claro, Rio Claro, Brazil; ${ }^{\text {d} C e n t r o ~ d e ~ E s t u d i o s ~ F o t o s i n t e ́ t i c o s ~ y ~}$ Bioquímicos, Universidad Nacional de Rosario, Rosario, Argentina; 'Departamento de Tecnologia Bioquímico-Farmacêutica, Faculdade de Ciências Farmacêuticas, Universidade de São Paulo, São Paulo, Brazil
\end{abstract}

\begin{abstract}
Antarctica is the coldest, windiest, and driest continent on Earth. In this sense, microorganisms that inhabit Antarctica environments have to be adapted to harsh conditions. Fungal strains affiliated with Ascomycota and Basidiomycota phyla have been recovered from terrestrial and marine Antarctic samples. They have been used for the bioprospecting of molecules, such as enzymes. Many reports have shown that these microorganisms produce cold-adapted enzymes at low or mild temperatures, including hydrolases (e.g. $\alpha$-amylase, cellulase, chitinase, glucosidase, invertase, lipase, pectinase, phytase, protease, subtilase, tannase, and xylanase) and oxidoreductases (laccase and superoxide dismutase). Most of these enzymes are extracellular and their production in the laboratory has been carried out mainly under submerged culture conditions. Several studies showed that the cold-adapted enzymes exhibit a wide range in optimal $\mathrm{pH}(1.0-9.0)$ and temperature $\left(10.0-70.0^{\circ} \mathrm{C}\right)$. A myriad of methods have been applied for cold-adapted enzyme purification, resulting in purification factors and yields ranging from 1.70 to 1568.00 -fold and 0.60 to $86.20 \%$, respectively. Additionally, some fungal cold-adapted enzymes have been cloned and expressed in host organisms. Considering the enzyme-producing ability of microorganisms and the properties of cold-adapted enzymes, fungi recovered from Antarctic environments could be a prolific genetic resource for biotechnological processes (industrial and environmental) carried out at low or mild temperatures.
\end{abstract}

ARTICLE HISTORY

Received 3 March 2017

Revised 28 July 2017

Accepted 1 August 2017

\section{KEYWORDS}

Antarctica; bioprospecting; cold-adapted enzymes; extremophiles; filamentous fungi; mycology; psychrophiles; yeasts

\section{Introduction}

Antarctica is a remote continent whose predominant characteristics include extreme low temperatures in winter (between -20.0 and $-50.0^{\circ} \mathrm{C}$ at the McMurdo Dry Valleys) and average temperatures below $0.0^{\circ} \mathrm{C}$, cycles of freezing and thawing, strong winds, high sublimation and evaporation rates, high radiation incidence, and long periods of darkness that limit the development of life [1]. Microorganisms inhabiting these environments may have a key role in the transport of energy, nutrient recycling and mineralization, providing the basis for the function of these terrestrial, and aquatic ecosystems $[1,2]$.

Due to their extremophilic adaptability, fungi from Antarctic environments have been a focus of research [3-5]. Cold-adapted enzymes are an important element of the survival strategy in Antarctic ecosystems and their properties could confer some advantages in biotechnological processes $[6,7]$. Some examples of cold-active enzymes from microorganisms have been reported (Cavicchioli et al. [8] and Marx et al. [9]). Although Cavicchioli et al. [8] evaluated the cold-active enzymes produced by bacteria, archaea, and fungi from cold environments; they did not obtain these microbes specifically from Antarctica. On the other hand, Marx et al. [9] contributions are related to the cold-adapted enzymes from marine Antarctic microorganisms, highlighting the comparison of these enzymes with their mesophilic counterparts. Fungi from Antarctic terrestrial samples have not been mentioned.

CONTACT Alysson Wagner Fernandes Duarte 0 alysson.duarte@arapiraca.ufal.br E Univesidade Federal de Alagoas, Campus Arapiraca, Manoel Severino Barbosa, s/n, Arapiraca 57309-005, Brazil; Lara Durães Sette larasette@rc.unesp.br E Universidade Estadual Paulistra (UNESP), Departamento de Bioquímica e Microbiologia, Universidade Estadual Paulistra, 24A, 1515, Rio Claro 13506-900, Brazil

(C) 2017 Informa UK Limited, trading as Taylor \& Francis Group 
Considering the ecological and biotechnological relevance of fungi from Antarctic ecosystems, this review reports the main cold-adapted enzymes produced by filamentous fungi and yeasts.

\section{Diversity of fungi recovered from Antarctic samples}

Microorganisms from Antarctic environments include representatives from all three domains, Bacteria, Archaea, and Eukarya [10]. They are classified as psychrophilic, psychrotolerant, and mesophilic-psychrotolerant. Psychrophilic microorganisms grow at maximum temperatures below $20.0^{\circ} \mathrm{C}$ with optimum growth temperatures lower than, or equal to, $15.0^{\circ} \mathrm{C}$. Psychrotolerant microorganisms have the ability to grow at low temperatures, with optimum growth temperatures varying from $>15.0$ and $\leq 25.0^{\circ} \mathrm{C}$, while mesophilic-psychrotolerant microorganisms have the ability to grow at low temperatures, with optimum growth temperatures $>25.0$ and $\leq 40.0^{\circ} \mathrm{C}$ [11].

Antarctic fungi were isolated from many terrestrial environments, including soils $[4,7,12-16]$, ornithogenic soils $[17,18]$, penguin, skua, and petrel dung and bird feathers [19], bryophytes [20,21], leaves from vascular plants [22-24], lichens and stones with lichens $[18,25,26]$, rocks $[27,28]$, ice-free rocks [29], and wooden structures [30,31]. On the other hand, fungi from Antarctic marine ecosystems have been isolated from sediments [18,32,33], seawater [12,33], sponges $[5,18,34]$, and macroalgae $[3,25,35,36]$.

Most fungal species recovered from Antarctica are common, possibly because this environment continuously receives microbial propagules from outside the Continent [2]. According to Margesin and Miteva [10], dispersal of microorganisms is possible through a combination of favorable climatic factors, such as winds and storms, in addition to dissemination by oceanic currents, dust, plant seeds, and birds.

Filamentous fungi from Antarctica belong mainly to the phylum Ascomycota. Representatives of the genera Pseudogymnoascus (formerly Geomyces) and Mortierella have frequently been isolated [7,36-38]. Other genera reported in the Antarctic environments include: Acremonium, Alternaria, Antarctomyces, Ascobolus, Aspergillus, Beauveria, Cadophora, Capnobotryella Chaetomium, Cladosporium, Dactylella, Davidiella, Embellisia, Entrophospora, Engyodontium, Epicoccum, Eurotium, Fusarium, Geomyces, Gyoerffyella, Lecanicillium, Leuconeurospora, Microdochium, Mycocentrospora, Penicillium, Phaeosphaeria, Phoma, Pseudogymnoascus, Tetracladium, Thelobolus, Trichoderma, and Verticillium $[3,4,22,23,26,39-41]$.
Conversely, the majority of yeasts recovered from Antarctica belong to the phylum Basidiomycota. Representatives of the genera Cryptococcus and Rhodotorula have frequently been isolated from Antarctic environments $[12,14,18,24]$. Other common genera from the phylum Basidiomycota reported in Antarctica are: Bensingtonia, Bullera, Cystofilobasidium, Dioszegia, Glaciozyma, Holtermanniella, Leucosporidium, Mrakia, Pseudozyma, Papiliotrema, Sporobolomyces, and Tausonia (formerly Guehomyces). Ascomycota yeasts commonly found in Antarctica belong to the genera Candida, Debaryomyces, Kodamaea, Meyerozyma, Metschnikowia, Wickerhamomyces, and Yamadazyma [3,18,24-26,33,41,42].

Metschnikowia australis and Naganishia antarctica (formerly Cryptococcus antarcticus) are supposed to be autochthonous in Antarctica [2,3]. Representatives of $M$. australis were recovered from seawater [33], macroalgae $[3,25,35,36]$, and sponge [34], whereas representatives of Naganishia antarcticus were isolated from soil, cold desert soil [39,43], and rhizosphere soil [33]. Considering the advances in the microbial taxonomy, some of the yeast species found in Antarctica are being reclassified $[44,45]$. However, a comprehensive nomenclatural revision is beyond the scope of this review; the nomenclature presented in this work is that originally presented in previous literature.

The growing number of new fungal taxa from Antarctica indicates an apparently hidden diversity in this environment. Besides, next-generation sequencing technologies and metagenomics approaches proved to be effective for the knowledge and comparison of the Antarctic microbial communities [46,47]. The following new fungal species isolated from Antarctic samples have recently been described: Cystobasidium portillonense sp. nov. (formerly Rhodotorula portillonensis) [48]; Piskurozyma fildesensis sp. nov. (formerly Cryptococcus fildesensis) [49]; Leucosporidium escuderoi f.a., sp. nov. [50]; Taphrina antarctica f.a. sp. nov. [51]; Naganishia vaughanmartiniae sp. nov. (formerly Cryptococcus vaughanmartiniae) [52]; Cystobasidium tubakii sp. nov. and Cystobasidium ongulense sp. nov. [53], and Antarctomyces pellizariae sp. nov. [54].

\section{Adaptations to the Antarctic environments}

Low temperatures cause injuries to biological systems, such as an increase in cellular viscosity, intracellular oxidative stress, the formation of ice crystals, a reduction in membrane fluidity, a decrease in solute diffusion, stabilization of inhibitory nucleic acid structures, and reductions in the molecular interactions and biochemical reaction rates [55-57]. 


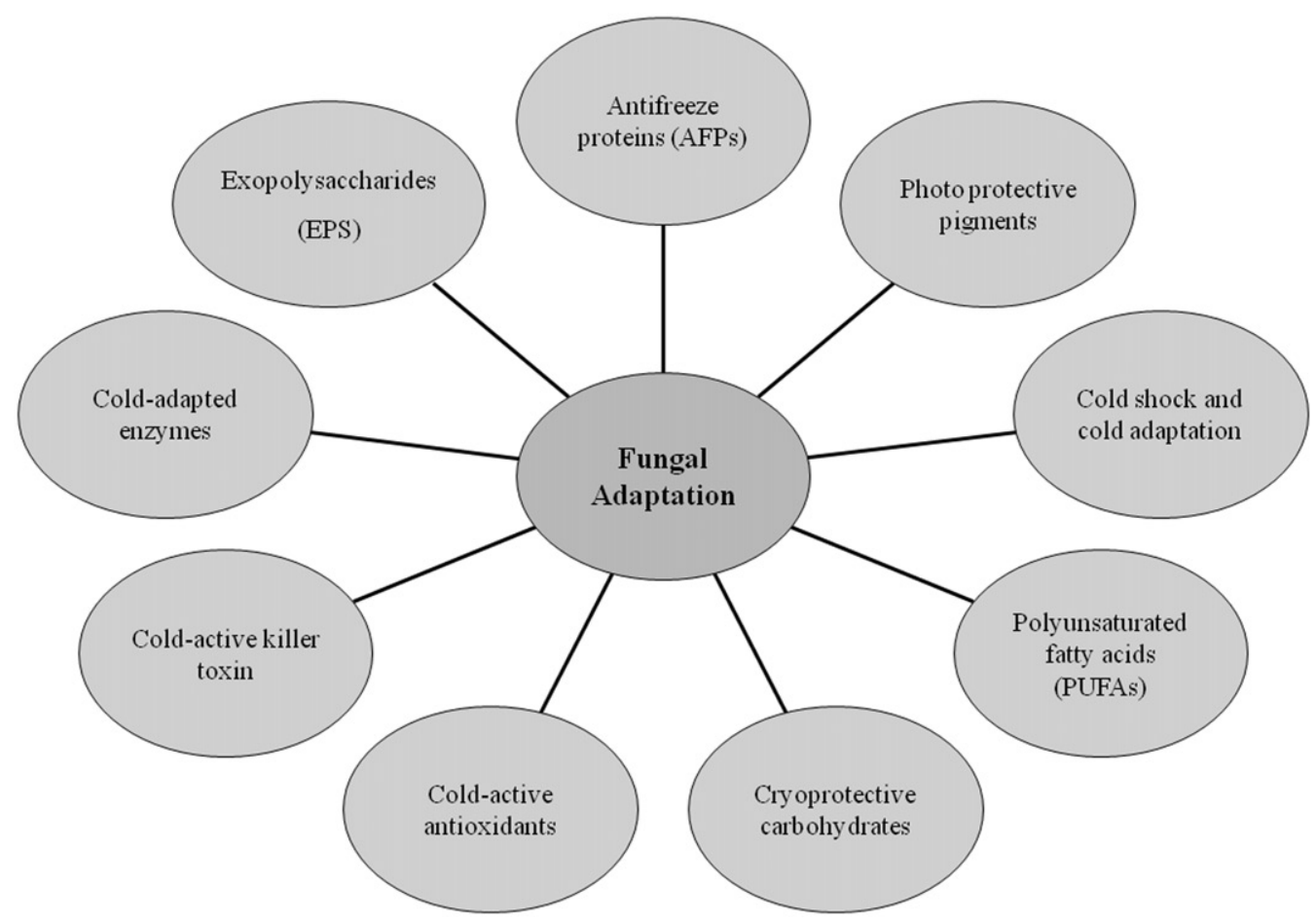

Figure 1. Main fungal adaptations to Antarctic conditions.

Survival in "extreme" environmental conditions requires a vast array of ecological and evolutionary adaptations, which are expressed at physiological, metabolic, and structural levels [27,55-57]. Survival strategies that have been observed in fungi recovered from Antarctic environments are summarized in Figure 1.

\section{Cold-adapted enzymes}

\section{Definition and properties}

Pioneering studies of psychrophilic microorganisms at the molecular level focused mainly on cold-active enzymes because this was considered as a prerequisite for environmental adaptation [58,59]. Cold-adapted enzymes are characterized by increased turnover and inherent catalytic efficiency at low temperatures. Because of their flexible structures, these enzymes show reduced activation enthalpy and negative entropy of activation compared to enzymes produced by mesophilic and thermophilic homologs [59].

The increase in flexibility has been proposed as a major molecular mechanism for the evolution of coldadapted enzymes and relates to a combination of the following features [60-62]: (i) a decrease in core hydrophobicity, an increase in surface hydrophobicity, a lower arginine/lysine ratio, weaker inter-domain and inter-subunit interactions, and more and longer loops; (ii) a prevalence of $\alpha$-helices in the secondary structure; (iii) a decrease in the secondary structure content, less and weaker metal-binding sites, and a reduction in the number of disulfide bridges and electrostatic interactions; and (iv) a reduction in the oligomerization and an increase in the nonconformational entropy of the unfolded state.

Because of their structure, cold-adapted enzymes have properties that could be useful in many biotechnological processes. According to Feller and Gerday [58], these enzymes are up to tenfold more active at low/moderate temperatures than their mesophilic homologs, offering economic benefits by reducing energetic costs of the production processes conducted at moderate temperatures $\left(25.0-40.0^{\circ} \mathrm{C}\right)$; they can be inactivated by temperature before unfolding of the protein structure; and their heat-lability (mainly in psychrophilic and psychrotolerant microorganisms) can propitiate selective inactivation in complex mixtures.

\section{Enzymes produced by fungi of Antarctic origin}

Overall, there are two approaches to assess microbial resources including enzymes: based on the screening of microbial strains and based on the screening of genomic libraries. However, there is a lack of information related to the prospecting of Antarctic enzymes based on the metagenomic approach (culture-independent techniques). It is worth mentioning that metagenomics allows one to explore new environments for putative functions, but still the culturable strains are necessary 


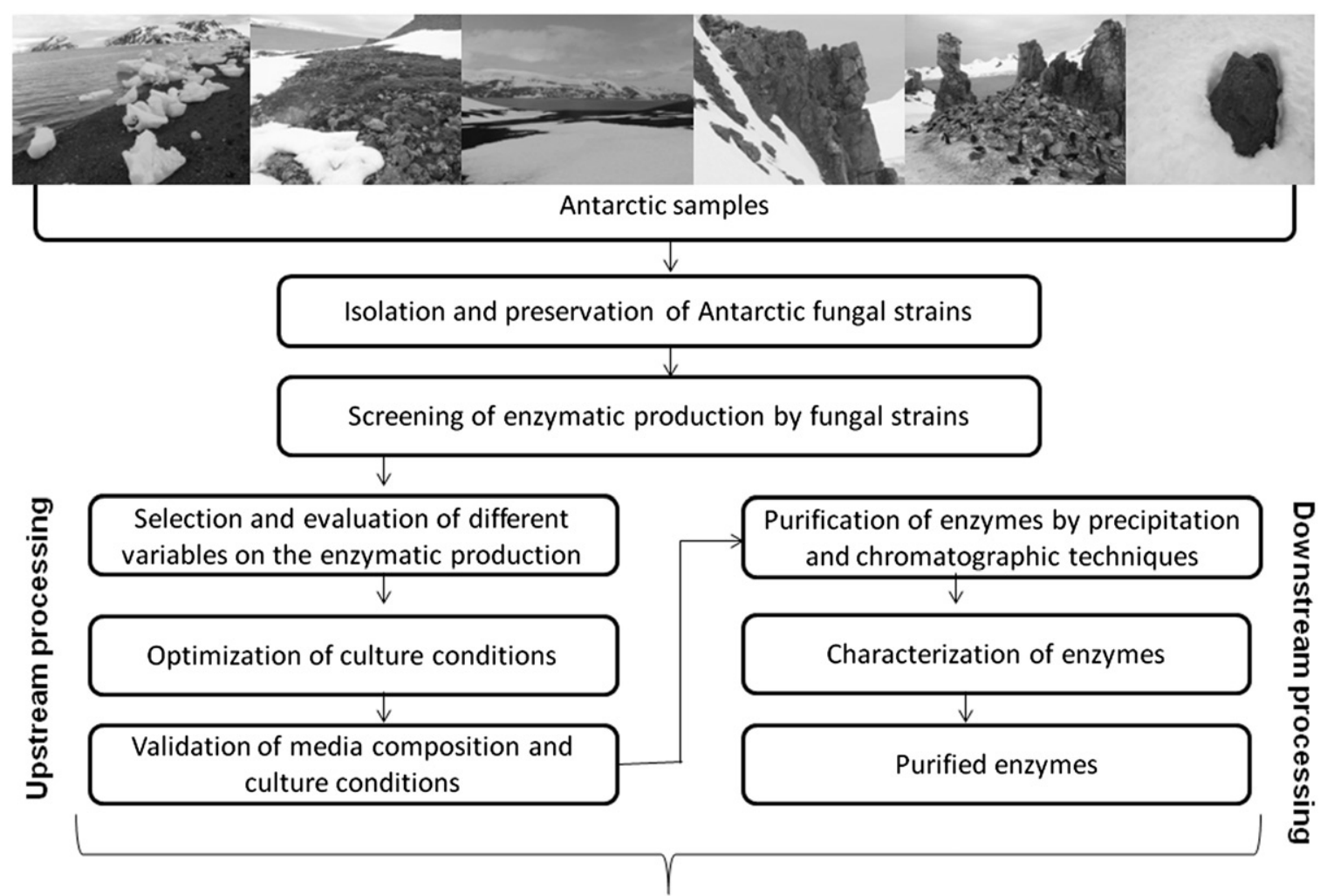

Biotechnological application of enzymes produced by the Antarctic fungi

Figure 2. Prospecting of enzymes produced by fungi from Antarctica.

for applied studies. In this sense, this review only presents the data related to screening and production of enzymes using the culture-dependent approach (Figure 2).

The method commonly used to screen fungal enzymes is the halo/colony ratio, which is performed in solid media to quantify extracellular enzymatic activity. The culture conditions and characteristics of some enzymes produced by filamentous fungi and yeasts of Antarctic origin are described in Table 1. The majority of the enzymes are classified as hydrolases. However, some oxidoreductases, such as laccase and superoxide dismutase have also been reported. The enzyme production presented in Table 1 is mainly carried out under submerged cultures.

Some fungal species isolated from Antarctic samples show the ability to produce enzymes at 28.0, 29.0, and $37.0^{\circ} \mathrm{C}$, emphasizing the potential to respond to higher growth temperatures. According to Pesciaroli et al. [11], microbes capable of growing across a wide spectrum of temperatures are more versatile in relation to environmental changes and able to colonize a wide range of ecological niches in cold environments. These microorganisms are defined as eurythermics and may be useful for industrial processes. On the other hand, the majority of enzyme production was carried out at low and moderate temperatures (ranging from 4.0 to $26.0^{\circ} \mathrm{C}$ ), highlighting the potential of Antarctic fungi for biotechnological applications at low/moderate temperatures. It is important to mention that the optimum temperatures for enzymatic activity of many enzymes were higher than those used for enzyme production (Table 1).

The enzymes presented in Table 1 are produced by fungi of Antarctic origin, which belong to the genera Cystobasidium, Cystofilobasidium, Debaryomyces, Dioszegia, Glaciozyma, Goffeauzyma, Leucosporidium, Moesziomyces, Mrakia, Naganishia, Papiliotrema, Phenoliferia, Rhodotorula, Tausonia, Vanrija (yeasts) and Acremonium, Alternaria, Aspergillus, Cladosporium, Geomyces, Lecanicillium, Penicillium, Phoma, Pseudogymnoascus, Trichoderma, and Verticillium (filamentous fungi).

The production of polysaccharide metabolizing enzymes by Antarctic fungal strains from terrestrial samples can be explained by the availability of nutrients in these environments. On the other hand, in marine environments the presence of polysaccharides (except for chitin) is not evident, suggesting that the ocean could not be their natural reservoir. Fungal strains, recovered 


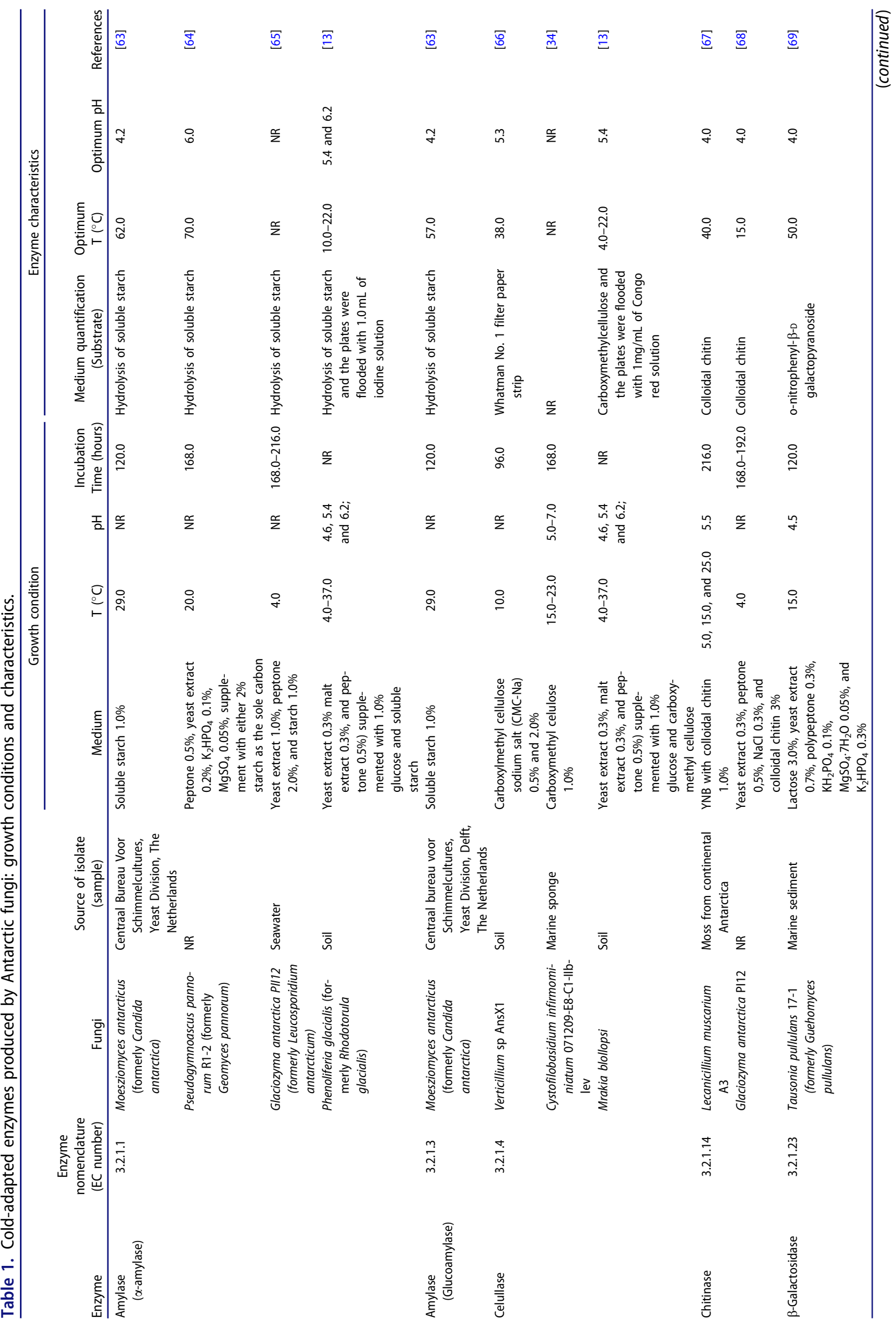


CRITICAL REVIEWS IN BIOTECHNOLOGY $\Leftrightarrow 605$

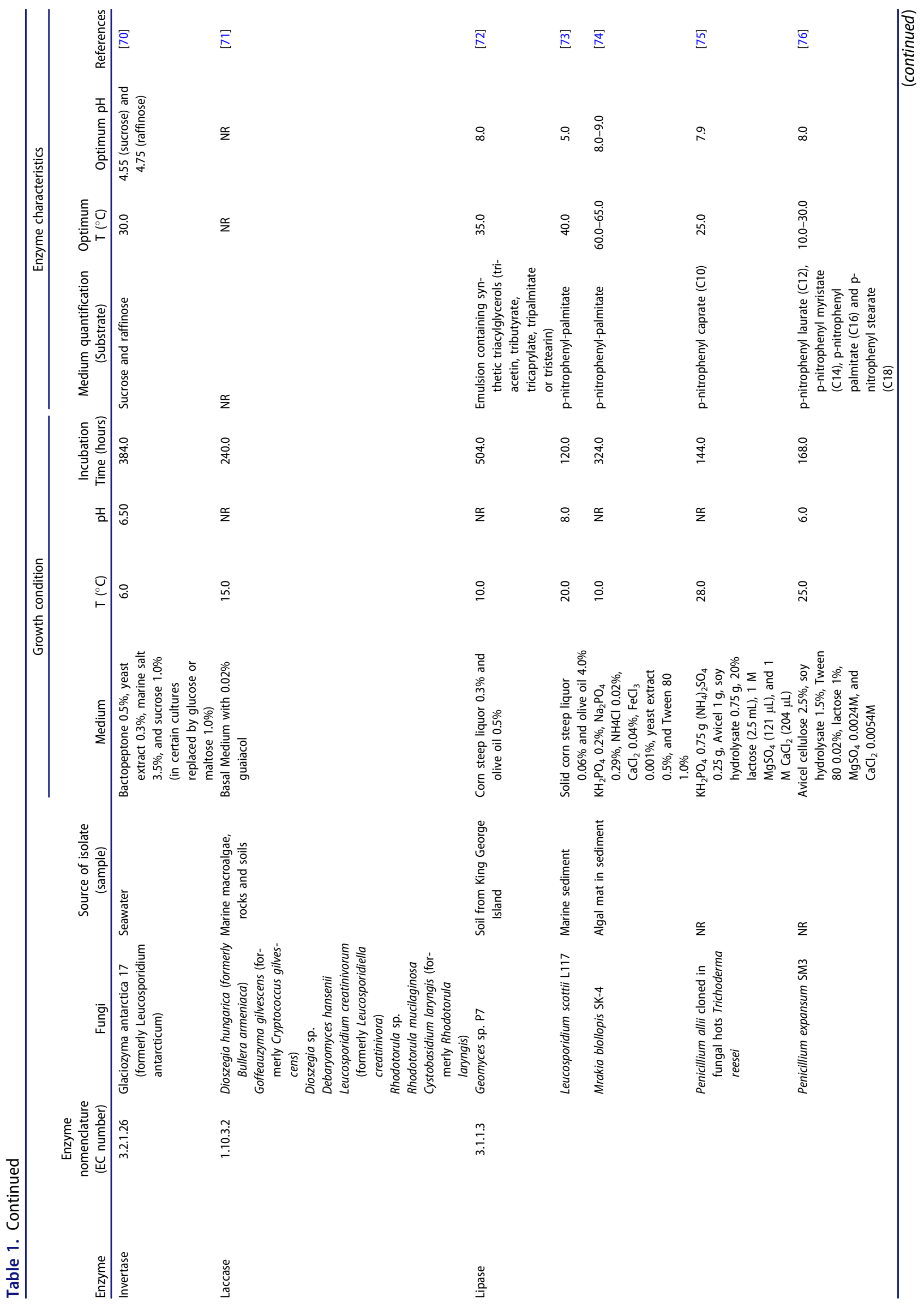




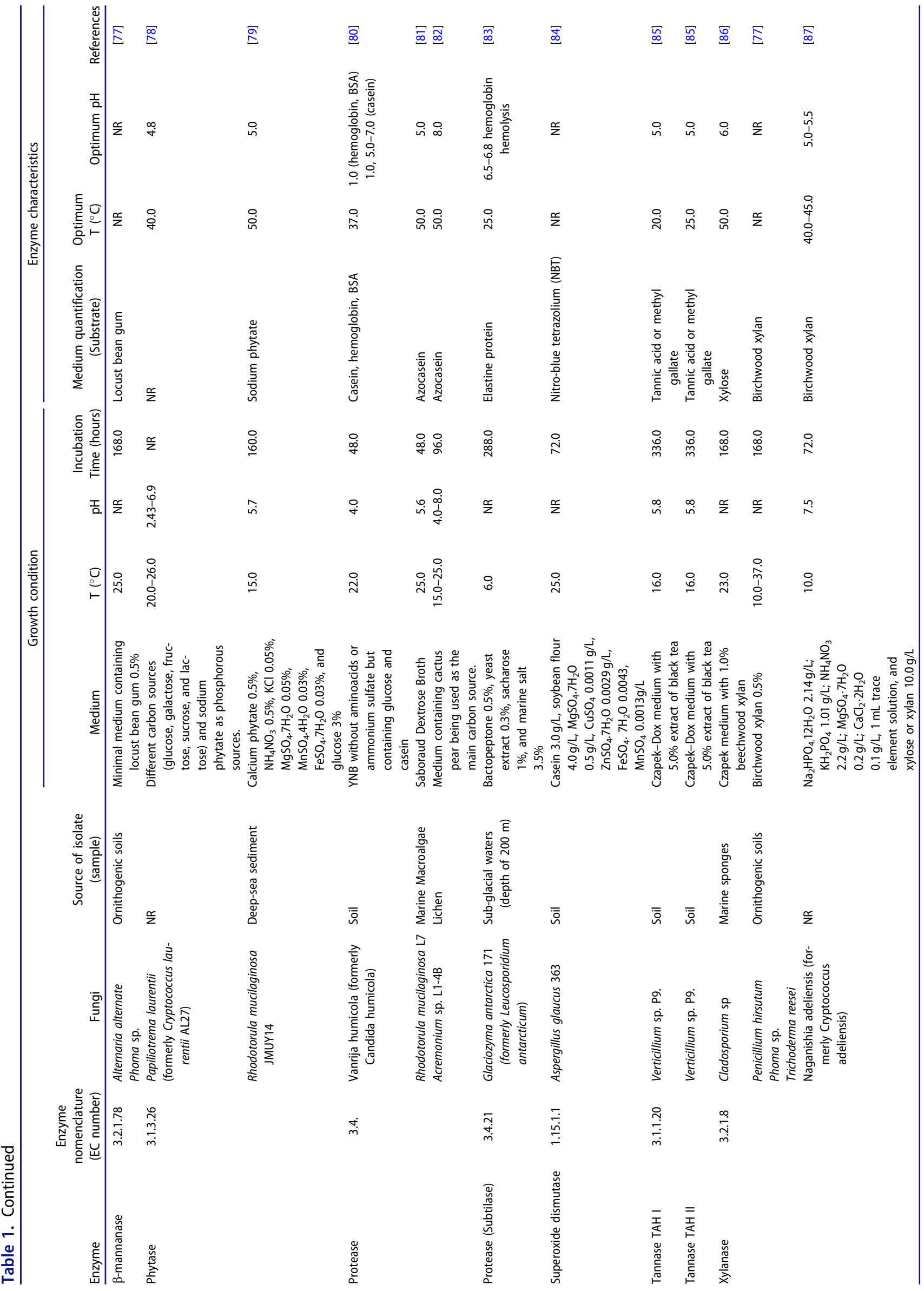


from tissues of marine sponges, are present as spores and/or propagules derived from the water but do not necessarily form an ecological association with the invertebrate [88].

\section{Hydrolytic enzymes}

\section{Cellulases}

The production of cellulases has been reported by Antarctic fungi isolated from marine sponges [34], soil $[13,66]$, ornithogenic soils $[7,77]$, and from wood and other organic materials [89-91]. The introduction of wood and other organic materials for human survival by early explorers may have introduced exogenous fungi and new nutrient sources for the indigenous fungi. Wood degradation in Antarctic sites appears to occur via "soft rot" by asexual ascomycetes, rather than by "white rot" or "brown rot" basidiomycete species [30-31,89-93].

For the screening of cellulases from fungi of Antarctic origin, media supplemented with carboxymethylcellulose as a carbon source have been used $[34,66,77]$. Filamentous fungi recovered from Antarctic samples that belong to the genera Cadophora Cladosporium, Geomyces, Penicillium, Pseudeurotium, Pseudogymnoascus, Verticillium, and Wardomyces have shown the ability to produce cellulases $[7,66,89,90]$. The production of these enzymes was also observed in Antarctic yeasts belonging to the genera Cryptococcus and Mrakia [7,13,33,94]. Additionally, Penicillium roqueforti, Cadophora malorum, Geomyces sp., and Mrakia blollopis can grow and use cellulose substrates in temperatures ranging from 4.0 to $22.0^{\circ} \mathrm{C}[13,89,90]$.

Cold-adapted cellulases can be used in the textile and paper industries, in cotton processing, paper recycling, detergent production, juice extraction, as animal feed additives, and for biofuel production $[13,66,95,96]$. Cold-adapted cellulolytic enzymes tolerant to organic solvents can be used for manufacturing volatile and heat-sensitive compounds such as flavors, fragrances, and perfumes [97].

\section{Xylanases}

Fungi able to produce xylanases have been isolated from Antarctic samples including ornithogenic soil [77], soil [12], and marine invertebrates $[18,34,86]$. Screening of xylanases produced by Antarctic fungi was performed using substrates such as birchwood xylan, beechwood xylan, and wheat bran. Representatives of fungi from the genera Alternaria, Candida, Cryptococcus, Dioszegia, Naganishia, Penicillium, Tausonia,
Trichoderma, and Phoma were reported as xylanase producers $[12,18,77,87,98]$.

In the study performed by Del-Cid et al. [87], the fungus Cladosporium sp., recovered from Antarctic marine sponge, showed high xylanolytic activity at low temperatures using pure xylans from hardwoods (birchwood and beechwood). Duarte et al. [18] reported the production of xylanases by almost all of the Basidiomycota yeasts (80.56\%) recovered from Antarctic samples. In the study carried out by Gomes et al. [87], the definition of culture medium composition using statistical design increased the enzymatic activity of Naganishia adeliensis (formerly Cryptococcus adeliensis) 4.3 -fold at $4.0^{\circ} \mathrm{C}$. According to Petrescu et al. [98], the tridimensional model of xylanase produced by Naganishia adeliensis shared $84 \%$ identity with the xylanase produced by its mesophilic counterpart Naganishia albida (formerly Cryptococcus albidus). However, the xylanase from Naganishia adeliensis was less thermostable than the one produced by Naganishia albida. Additionally, in the temperature range of $0.0-20.0^{\circ} \mathrm{C}$, the cold-adapted xylanase produced by Naganishia adeliensis displayed lower activation energy and higher catalytic efficiency, suggesting a less compact, and more flexible molecular structure. Cold-adapted xylanases can be applied in the production of flour and biofuel, in the field of bioremediation, and for the generation of chemicals from lignocellulose [87].

\section{Pectinases}

The majority of fungal strains with pectinase activity were recovered from the marine environment in Antarctica. In the study reported by Fenice et al. [99], more than $50 \%$ of Antarctic fungal strains produced extracellular polygalacturonase and/or pectin lyase. Representatives of Antarctic fungi from the genera Arthrobotrys, Aureobasidium, Cladosporium, Leucosporidium showed the ability to produce pectinases $[33,99]$. Cold-adapted pectinases can be used in the food processing industry in fruit juice clarification, juice wastewater treatment, and to improve the quality of wines [100].

\section{Chitinases}

Antarctic fungal strains able to produce chitinases have been isolated from soil samples [12] and sandstone rocks [28]. Representatives of the genera Phoma, Lecanicillium, Leuconeurospora, Dioszegia, Mrakia, Metschnikowia, Sporidiobolus, and Glaciozyma were reported as chitinase producers [12,28,67,68, 99,101,102]. According to Ramli et al. [68], 
chitin comprises approximately $20-58 \%$ of the dry weight of marine environment organisms, such as shrimp, crabs, squid, oysters, and krill, the latter being considered the main component of the Antarctic food chain.

In the study reported by Fenice et al. [102], the yield of chitinase production in a bioreactor by Lecanicillium muscarium CCFEE-5003 was higher from shrimp shells than from crab shells. This strain produced a complex enzymatic system comprising five proteins that act on chitin [103]. These chitinolytic enzymes have MWs and isoelectric points ranging from ca. 20.0 to $75.0 \mathrm{kDa}$ and pH 4.5 to 5.0, respectively [104]. Two additional chitinolytic enzymes (CHI1 and $\mathrm{CH} 2$ ) presented differences in chitin hydrolysis and were defined as "chitobiase" and "exo-chitinase", respectively [102-104].

The structure of psychrophilic chitinase (CHI II) from Glaciozyma antarctica PI12 was elucidated by Ramli et al. [61]. The authors found that the enzyme has low sequence identity with other chitinase sequences and observed that, similar to other psychrophilic enzymes, the substitutions of certain amino acids in the surface and loop regions conferred an increase in the flexibility of the enzyme, as a result of adaptation to cold temperatures.

Chitinases with activity at low temperatures have significant advantages in industrial applications, such as the treatment of residues and control of microbial contamination in refrigerated foods and increasing shelf life $[68,101]$. Additionally, cold-adapted chitinases can be used in the treatment of chitin-rich waste at low temperatures, biocontrol of microbial spoilage, and phytopathogens [68].

\section{Proteases}

Antarctic fungi able to produce proteases were recovered from soil $[7,12,80,99]$, marine invertebrates and macroalgae [18,34], melt water [12], and lichens [82]. Protease screening has been measured in solid media with skim milk, defatted milk, or casein. In liquid media, the proteolytic activity has been usually determined in the presence of azocasein as substrate.

Antarctic fungi reported as protease producers belong to the genera: Acremonium, Candida, Cryptococcus, Chrysosporium, Embellisia, Exophiala, Geomyces, Glaciozyma, Glomerella, Leuconeurospora, Leucosporidium, Mrakia, Phoma, Pseudogymnoascus, Rhodotorula, Trichoderma, Vanrija, and Wickerhamomyces [12,18,33,34,80-83,99,105]. In most cases, the secretion of proteases was dependent on the medium composition, temperature, and the phase of growth [80-82]. In the study performed by Duarte et al.
[18], 14\% of the Antarctic yeasts were able to produce proteases in solid and liquid media. Rhodotorula mucilaginosa L7 produced the greatest amounts of enzyme [106]. The extracellular acid protease from the R. mucilaginosa $\mathrm{L} 7$ was active at temperatures ranging from 15.0 to $60.0^{\circ} \mathrm{C}$ [81].

According to Ray et al. [80], the protease of Vanrija humicola (formerly Candida humicola) was active at temperatures ranging from 0.0 to $45.0^{\circ} \mathrm{C}$ and was resistant to freeze-thaw cycles. In the study reported by Turkiewicz et al. [107], the serine protease secreted by Glaciozyma antarctica 107 (formerly Leucosporidium antarcticum) was most active at $25.0^{\circ} \mathrm{C}$ and exhibited activity even at $-10.0^{\circ} \mathrm{C}$. On the other hand, the serine protease purified from Acremonium sp. L1-4B was active at temperatures ranging from 10.0 to $40.0^{\circ} \mathrm{C}$ [82]. In another study, the protease produced by Pseudogymnoascus pannorum (formerly Geomyces pannorum) exhibited the greatest activity at $4.0^{\circ} \mathrm{C}$ [7].

Cold-adapted proteases can be used in the food industry to accelerate cheese ripening, softening frozen/refrigerated meat products, preserving the quality of heat-sensitive nutrients, and can also be effective against haze-producing proteins in winemaking and brewing. In the textile industry, these proteases can be used in detergents and soap powder for dirt removal for "cold washing" processes and washing textiles at room temperature $[57,105,107,108]$.

\section{Lipases}

The production of esterases and lipases by Antarctic fungi may be associated with the mechanisms of cold tolerance since the maintenance of cell membrane fluidity is essential to survival and may be achieved by increasing the degree of unsaturation of fatty acids $[109,110]$.

Representatives of Antarctic fungi belonging to the genera Beauveria, Candida, Cryptococcus, Geomyces, Leucosporidium, Moesziomyces, Mrakia, Pseudozyma, Penicillium, Phoma, Pseudogymnoascus, Verticillium, and Trichosporon were reported to be lipase producers $[18,33,72-74,76,99,111-113]$. Substrates used for lipase production by Antarctic fungal strains include vegetable and fish oils, animal fats, synthetic triacylglycerides, and Tween 20, 40,60, and 80. Lipases can be screened using carbon sources, such as olive oil plus rhodamine B $[18,77]$.

The yeast Moesziomyces antarcticus (formerly Candida antarctica) is the best-known fungus of Antarctic origin with industrial applications [42]. This yeast produces two lipases, $A$ and $B$, the latter being sold as Novozym 435 by Novozymes (Bagsvaerd, 
Denmark) [114]. Lipase B is involved in many organic synthesis applications related to food and feed processing, pharmaceuticals, and cosmetics [113].

The yeast Leucosporidium scottii L117 isolated from an Antarctic marine sediment can produce lipase at $20.0^{\circ} \mathrm{C}$ in medium containing olive oil and corn steep liquor as carbon and nitrogen sources, with optimal activity levels at $40.0^{\circ} \mathrm{C}$ [73]. In the study performed by Tsuji et al. [74], lipase from Mrakia blollopis SK-4 remained stable in a wide range of temperatures. Additionally, the lipase produced by the Antarctic fungus Geomyces sp. P7 has an optimum temperature between 8.0 and $35.0^{\circ} \mathrm{C}$ (with $15 \%$ of maximum activity at $0.0^{\circ} \mathrm{C}$ ) and performs enantioselective transesterification of 1-phenylethanol with vinyl acetate [72].

Lipases from psychrophilic/psychrotolerant fungi have drawn attention because of their potential for biotechnological applications, including in the food and beverage, chemical, and pharmaceutical industries [115]. These enzymes can also be used in the composition of cleaning products, in the conversion of vegetable oils to biodiesel, for the decomposition of milk at low temperatures, in wastewater treatment, especially in temperate regions, and the cleaning of oil spills $[15,60,74,109,116,117]$.

\section{$\alpha$-Amylases and glucoamylases}

Antarctic fungal strains representative of the genera Cryptococcus, Dioszegia, Glaciozyma, Holtermaniella, Leuconeurospora, Mrakia, Moesziomyces, Penicillium, Pseudogymnoascus, Rhodotorula, Phenoliferia, and Thelebolus were reported to be amylase producers $[12,13,32,62-65,99,118]$. Amylase activity has been assayed by growing the selected strains on media supplemented with starch as a carbon source.

In the study reported by De Mot and Verachtert [63], $\alpha$-amylase and glucoamylase from Moesziomyces antarcticus CBS 6678 (Candida antarctica) were purified; both act preferentially on high-molecular-mass substrates, with $\alpha$-amylase being active on cyclodextrins. Ramli et al. [62] elucidated the structure of a novel cold-active $\alpha$-amylase produced by Glaciozyma antarctica PI12. This enzyme showed the presence of binding sites for a conserved calcium ion (Cal), non-conserved calcium ions (Call and CallI), and sodium ion ( $\mathrm{Na}$ ). The authors suggest that the low stability of this enzyme is related to its ability to act at different temperatures.

Amylases can be used in a wide range of industries, including baking, paper, textiles, brewing, and detergents $[13,118]$. Cold-adapted amylases that are inactivated by heat are important in the food industry because they can prevent modification of heat-sensitive substrates and products [119].

\section{Other hydrolytic enzymes}

According to the literature, fungi of Antarctic origin can produce other hydrolytic enzymes, including $\beta$-galactosidases, tannases, phytases, $\beta$-mannanases, and invertases (Table 1). However, data related to these coldadapted enzymes remains scarce.

$\beta$-galactosidases can be applied in the food and pharmaceutical industries, including for sugar reduction in different foods, development of additives for animal and human diets, and bioconversion of milk whey to reduce industrial effluents [69]. Zhang et al. [120], reported that the marine Antarctic yeast Tausonia pullulans 17-1 (formerly Guehomyces pullulans) showed highest extracellular $\beta$-galactosidase activity in a medium containing only lactose as the carbon source.

Tannases are utilized in a number of industrial applications, including the manufacture of instant tea, beer, fruit juices, some wines, and gallic acid production [121]. In the study performed by Kasieczka-Burnecka et al. [85], two Antarctic cold-adapted extracellular tannases (TAH I and TAH II) produced by Verticillium sp. P9 were purified and presented optimum activities at 25.0 and $20.0^{\circ} \mathrm{C}$, respectively.

Cold-adapted phytases might have considerable advantages in direct inclusion in feed for monogastric animals and use in aquaculture [79]. Pavlova et al. [78] reported that Papiliotrema laurentii AL27 (formerly Cryptococcus laurentii) showed highest intracellular phytase activity at an optimal temperature of $40.0^{\circ} \mathrm{C}$. In another study, Yu et al. [79] reported the production of extracellular phytase by Rhodotorula mucilaginosa JMUY14, which showed resistance to both pepsin and trypsin degradation after purification.

$\beta$-Mannanases are used in the production of animal feed and laundry detergents, also being applied in the pulp, paper, food, pharmaceutical, and energy industries [122]. According to Bradner et al. [77], fungi from the genera Penicillium and Phoma recovered from ornithogenic soils in Antarctica presented high levels of mannanase activity at $0.0^{\circ} \mathrm{C}$. Parvizpour et al. [122] elucidated a novel psychrophilic $\beta$-mannanase from Glaciozyma antarctica PI12. The enzyme exhibited adaptations related to molecular flexibility and enzymatic efficiency at low temperatures.

Fungal invertases are used mainly in the production of invert sugars to be employed in the food and beverage industries [70]. Turkiewicz et al. [70] reported the production of an intracellular fructofuranosidase by the Antarctic yeast Glaciozyma antarctica 171 (formerly 
Leucosporidium antarcticum), with an optimum temperature of $30.0^{\circ} \mathrm{C}$.

\section{Oxidoreductases}

\section{Laccases}

Despite the relevance of these enzymes for industrial and environmental applications, studies related to their production by Antarctic fungi are scarce. Rovati et al. [71] reported the ability of yeasts recovered from different Antarctic samples to produce laccase at $15.0^{\circ} \mathrm{C}$ in a medium supplemented with guaiacol, useful for textile dyes and lignin degradation. Guaiacol has been widely employed as a substrate for ligninolytic enzymes, such as laccase, peroxidases, and lignin peroxidase because an intense reddish-brown color is produced in the medium around laccase-producing organisms in the presence of this compound [123].

Ligninolytic enzymes produced at low/moderate temperatures can be applied for pollutant degradation in cold environments or processes [57]. In this context, some studies have reported the ability of fungi of Antarctic origin to grow and/or degrade environmental pollutants. However, the involvement of laccases in these processes was not mentioned. Litova et al. [124] showed that three fungal strains recovered from Antarctic soil (Penicillium commune AL2, Aspergillus fumigatus AL3, and Penicillium rugulosum AL7) were able to utilize phenol as their sole carbon source at $5.0^{\circ} \mathrm{C}$. Gerginova et al. [125] reported that Antarctic fungi were able to tolerate and/or degrade polycyclic aromatic hydrocarbons, including phenanthrene (Alternaria maritima AL10), anthracene (Penicillium rugulosum AL7 and Penicillium waksmanii AL14), and naphthalene (Aspergillus fumigatus AL9, Penicillium chrysogenum AL12, and Mucor sp. AL13).

\section{Superoxide dismutases and catalases}

High concentrations of superoxide dismutase were produced by the Antarctic fungus Aspergillus glaucus 363 following cold stress at $10.0^{\circ} \mathrm{C}$ using a nitro-blue tetrazolium substrate [84]. Tosi et al. [126] reported catalase production by fungal strains recovered from soil samples belonging to the genera Aspergillus, Cladosporium, and Penicillium.

Cold-adapted antioxidant enzymes, such as superoxide dismutases and catalases can be very important for the prevention of skin injury when used in cosmetic formulations. These enzymes can also be used in medicine, as a pulp-capping agent, as an inhibitor of pulmonary vascular oxidative stress, and in the treatment of septic shock $[84,126]$.

\section{Heterologous expression}

Some of the cold-adapted enzymes, produced by Antarctic fungi, have been cloned and expressed in different hosts. Data related to host organisms, vectors, production and amino acid, and nucleotide sequences are presented in Table 2.

The expression of enzymes from eukaryotic organisms in bacteria can be unsatisfactory, mainly because of their lack of ability to secrete extracellular proteins; additionally, eukaryotic post-translational modifications do not occur in prokaryotic organisms. Therefore, the expression must be performed in other eukaryotic organisms; $P$. pastoris appears to be a good host for fungal cold-adapted enzyme expression. According to Gao et al. [64], the $\alpha$-amylase from Pseudogymnoascus pannorum R2-1 (formerly Geomyces pannorum) cloned in $P$. pastoris presented low homology to other $\alpha$-amylases, with thermophilic characteristics (optimal activity at $70.0^{\circ} \mathrm{C}$ ). In another study, Ramli et al. [68] reported that the chitinase from $G$. antarctica PI12 expressed in $P$. pastoris was most active at $15.0^{\circ} \mathrm{C}$, being stable in the range of $5.0-25.0^{\circ} \mathrm{C}$. According to Feller and Gerday [58], a great contribution in this field could be associated with the use of a psychrophilic microorganism as a host for the expression of genes at low temperatures, preventing the formation of inclusion bodies and protecting heat-sensitive gene products.

\section{Purification of cold-adapted enzymes from Antarctic fungi}

Hydrolases and oxidoreductases produced by fungi of Antarctic origin have been purified and characterized (Table 3). The techniques used were diverse and yielded purification factors from 1.70- to 1568.00-fold and yield ranging from 0.65 to $86.20 \%$. Enzymes secreted into the medium by Antarctic fungi are first concentrated by techniques, such as ultrafiltration $[68,74,80,81,98,130]$, ammonium sulfate precipitation [63,64], ammonium sulfate and dialysis [79,85], or acetone precipitation [107]. After concentrating, the protein, purification can be carried out by a single or multiple steps of chromatography. In studies carried out by Lario et al. [81], Petrescu et al. [98], and Ray et al. [80], ion exchange chromatography was performed. On the other hand, in the studies reported by Abrashev et al. [84], De Mot and Verachtert [63], Florczak et al. [72], Gao et al. [64], Turkiewicz et al. [107], and Yu et al. [79] size exclusion with ion exchange and/or affinity chromatography were combined. 


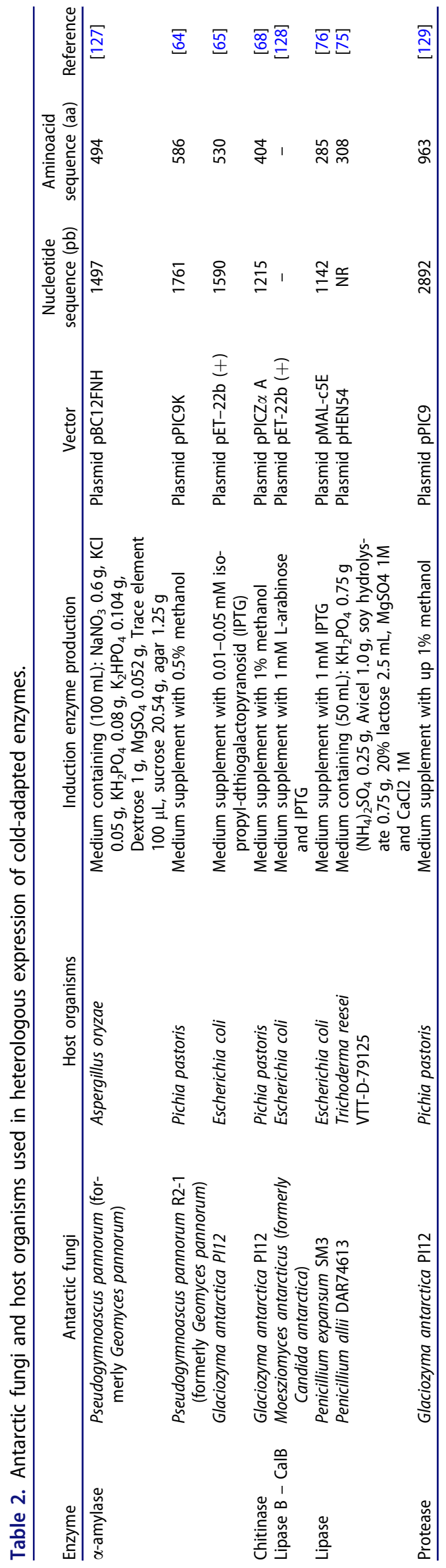

Purification of extracellular enzymes involves environmental concerns because of the use of large quantities of salts and the high costs associated with chromatographic steps. Because of this, the search for other separation methods is important. Liquid-liquid extraction has been used for cold-adapted enzyme purification and has proven to be efficient for lipase from Leucosporidium scottii L117 [73] and protease from the Rhodotorula mucilaginosa L7 [131].

\section{Patents}

To find patents (or patent requests) related to enzymes from Antarctic fungi, a survey of 14 databases from around the world was performed. A total of eight keywords were used to conduct the search and the results are listed in Table 4. Despite the high number of keywords used, the survey did not retrieve many relevant results, indicating that this environment has a great unexplored biotechnological potential.

Records of patents or requests are associated mostly with bacteria, such as the lipase from Bacillus pumilus from Antarctica (10-1596435-0000), the cold-adapted protease HSPA-2 from a marine bacterium (WO2013177834), and anticancer and antimicrobial compounds from Lakes Schirmacher Oasis' bacteria, in East Antarctica (US20110301216). Most patents of coldadapted enzymes recovered from Antarctic fungal strains are related to the lipase produced by Candida antarctica (Table 5).

An attempt to survey patents in a database known as BioProspector maintained by the Institute of Advanced Studies (United Nations University) was performed, but unfortunately this database no longer exists. It used to contain information about patents and genetic resources from both Arctic and Antarctic environments. Now that it is inaccessible, there is one less resource for the promotion of the research regarding on extreme environments.

\section{Conclusions and future perspectives}

Fungi from Antarctic environments demonstrate a remarkable ability to produce enzymes (hydrolases and oxidoreductases), suggesting that the fungal community plays an important role in decomposition processes within Antarctic ecosystems. The search for coldadapted enzymes produced by Antarctic fungi has been performed mainly using culture-dependent methods, which allowed for the structuring of fungal culture collections of Antarctic origin. Although several studies in this field are being conducted, knowledge about microorganisms and their adapted biomolecules 
$612 \fallingdotseq$ A. W. F. DUARTE ET AL.

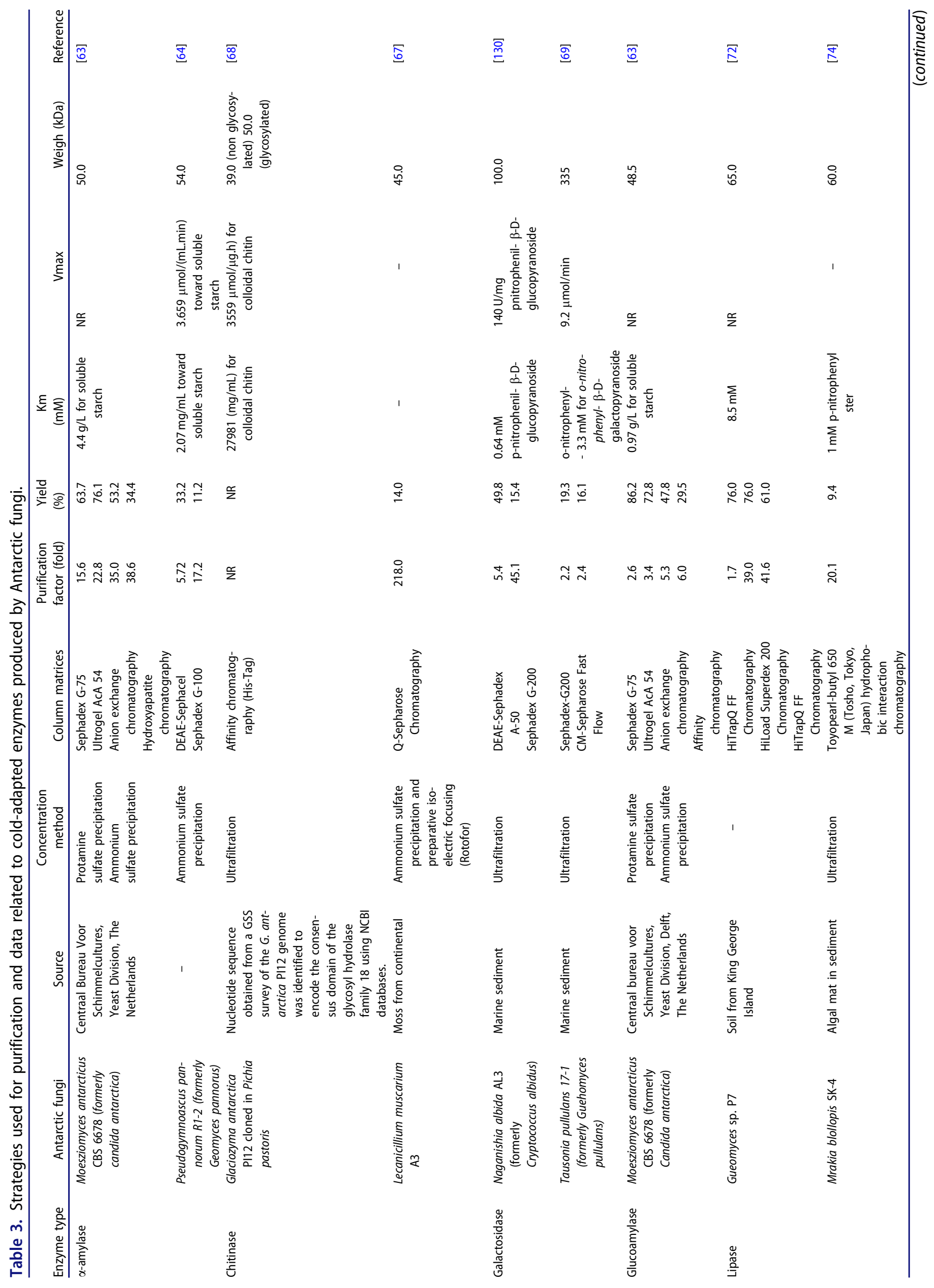


CRITICAL REVIEWS IN BIOTECHNOLOGY -613

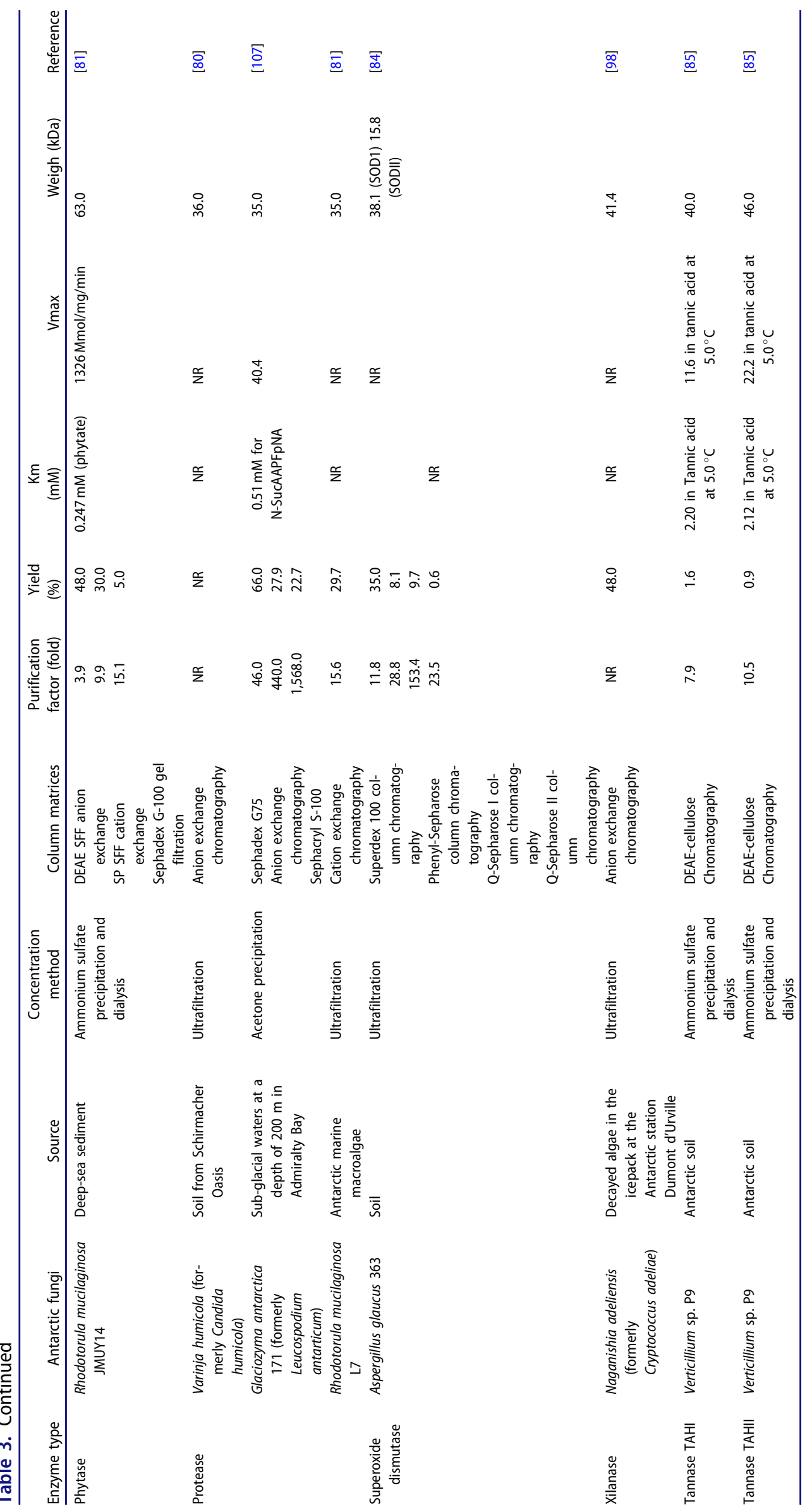


Table 4. Databases and keywords used to find patents (or requests) related to enzymes from Antarctic microorganisms.

\begin{tabular}{|c|c|c|c|c|c|c|c|c|}
\hline \multicolumn{9}{|c|}{ Keywords } \\
\hline Database & $\begin{array}{l}\text { "Cold } \\
\text { adapted } \\
\text { enzymes" }\end{array}$ & $\begin{array}{l}\text { "Antarctic } \\
\text { Microorganisms" }\end{array}$ & $\begin{array}{c}\text { "Antarctic cold } \\
\text { adapted } \\
\text { enzymes" }\end{array}$ & $\begin{array}{l}\text { "Psychrophilic } \\
\text { enzymes" }\end{array}$ & $\begin{array}{l}\text { "Enzyme } \\
\text { fungus } \\
\text { Antarctica" }\end{array}$ & $\begin{array}{c}\text { "Cold } \\
\text { adapted } \\
\text { lipase" }\end{array}$ & $\begin{array}{c}\text { "Cold } \\
\text { adapted } \\
\text { protease" }\end{array}$ & $\begin{array}{c}\text { "Cold } \\
\text { adapted } \\
\text { xylanase" }\end{array}$ \\
\hline European Patent Office & 6 & 3 & 1 & 3 & 0 & 0 & 0 & 0 \\
\hline World intellectual property organization (WIPO) & 13 & 4 & 3 & 26 & 0 & 0 & 0 & 0 \\
\hline $\begin{array}{l}\text { Korean intellectual property rights information } \\
\text { service (KIPRIS) }\end{array}$ & 1 & 0 & 2 & 3 & 0 & 3 & 0 & 0 \\
\hline AusPat (Australia) & 0 & 0 & 0 & 0 & 0 & 0 & 0 & 0 \\
\hline Canadian intellectual property office & 0 & 0 & 0 & 1 & 0 & 0 & 0 & 0 \\
\hline Taiwan Patent Search System & 0 & 0 & 0 & 0 & 0 & 0 & 0 & 0 \\
\hline Swissreg IGE/IPI & 0 & 0 & 0 & 0 & 0 & 0 & 0 & 0 \\
\hline Swedish patent database & 0 & 0 & 0 & 0 & 0 & 0 & 0 & 0 \\
\hline Norwegian industrial property office & 0 & 0 & 0 & 0 & 0 & 0 & 0 & 0 \\
\hline BPP - Benelux patent platform & 0 & 0 & 0 & 0 & 0 & 0 & 0 & 1 \\
\hline Israel patent office & 0 & 0 & 0 & 0 & 0 & 0 & 0 & 0 \\
\hline DPMA/Germany & 0 & 0 & 0 & 0 & 0 & 0 & 1 & 0 \\
\hline LATIPAT & 0 & 0 & 0 & 0 & 0 & 0 & 0 & 0 \\
\hline INPI (Brazil) & 0 & 0 & 0 & 0 & 0 & 0 & 0 & 0 \\
\hline
\end{tabular}

Table 5. Patents related to cold-adapted enzymes from Antarctic fungi.

\begin{tabular}{|c|c|c|c|c|}
\hline Patent number & Fungi source & Enzyme & Company/ Organization & Research field \\
\hline $\begin{array}{l}\text { US20080020088, EP1723229, } \\
\text { WO/2005/087916 }\end{array}$ & $\begin{array}{l}\text { Moesziomyces antarcticus (formerly } \\
\text { Candida antarctica) }\end{array}$ & Lipase & $\begin{array}{l}\text { AstraZeneca/ } \\
\text { Sweden, UK }\end{array}$ & Chemical processing \\
\hline \multicolumn{5}{|l|}{ NZ333445 } \\
\hline US5928933 & $\begin{array}{l}\text { Moesziomyces antarcticus (formerly } \\
\text { Candida antarctica) }\end{array}$ & Lipase & $\begin{array}{l}\text { Du Pont/ } \\
\text { USA }\end{array}$ & Chemical processing \\
\hline $\begin{array}{l}\text { US6020180 (2000), } \\
\text { EP0652945A1, US6074863, } \\
\text { W01994001541A1 }\end{array}$ & $\begin{array}{l}\text { Moesziomyces antarcticus (formerly } \\
\text { Candida antarctica) }\end{array}$ & Lipase & Novo Nordisk & Molecular biology/biotech \\
\hline US5407828 (1995) & $\begin{array}{l}\text { Moesziomyces antarcticus (formerly } \\
\text { Candida antarctica) }\end{array}$ & Lipase & $\begin{array}{l}\text { DSM NV/ } \\
\text { Netherlands }\end{array}$ & Chemistry \\
\hline KR20040066373 & $\begin{array}{l}\text { Moesziomyces antarcticus (formerly } \\
\text { Candida antarctica) }\end{array}$ & Lipase & $\begin{array}{l}\text { Korea Ocean Res } \\
\text { Dev Inst/ } \\
\text { Republic of Korea } \\
\text { Pais }\end{array}$ & Chemical processing \\
\hline KR20010092006 & $\begin{array}{l}\text { Moesziomyces antarcticus (formerly } \\
\text { Candida antarctica) }\end{array}$ & Lipase & $\begin{array}{l}\text { Shin Dong Bang Corp/ } \\
\text { Republic of Korea }\end{array}$ & Chemical processing \\
\hline JP2002262859 & KA-616 (mold) & & $\begin{array}{l}\text { Nagata Sangyo/ } \\
\text { Japan }\end{array}$ & Chemical processing \\
\hline
\end{tabular}

remains limited. In this sense, the use of a culture-independent approach, for both structural and functional analyses, could increase our knowledge related to the diversity and ecology of these microorganisms as well as expand the prospection of biomolecules, including those produced by non-cultivable microorganisms.

Considering the complexity and costs related to Antarctic expeditions, researchers involved in the prospecting steps (particularly the ones responsible for microbial isolation and preservation) should consider depositing these strains in an appropriate culture collection to ensure the maintenance of these valuable genetic resources. There are plenty of renowned culture collections all over the world, and many of them operate on the basis of international rules related to Access and Benefit Sharing - ABS (Nagoya Protocol).

Studies related to the prospecting, production, and characterization of Antarctic fungal enzymes should be encouraged since they could result in the isolation of new enzymes with different properties that can be used in environments and/or processes with low/mild temperatures. In this sense, national and international programs should be established to promote biotechnology advances in this area.

\section{Disclosure statement}

The authors report no conflicts of interest.

\section{Funding}

This work was supported by grants financed by FAPESP (reference numbers: \#2010/17033-0, \#2013/19486-0, and \#2016/ 07957-7) and by scholarships financed by CAPES and FAPESP (reference numbers: \#2010/08352-5, \#2012/23726-4, and \#2014/10207-4). LDS, AR, and APJ thank National Council for Scientific and Technological Development (CNPq) for Productivity Fellowships 304103/2013-6, 305341/2015-4, and 301248/2010-9. 


\section{ORCID}

Lara Durães Sette (D) https://orcid.org/0000-0002-5980-3786

\section{References}

[1] Onofri S, Selbman L, Hoog GS, et al. Evolution and adaptation of fungi at boundaries of life. Adv Space Res. 2007;40:1657-1664.

[2] Ruisi S, Barreca D, Selbmann L, et al. Fungi in Antarctica. Rev Environ Sci Biotechnol. 2007;6: 127-141.

[3] Godinho VM, Furbino LE, Santiago IF, et al. Diversity and bioprospecting of fungal communities associated with endemic and cold-adapted macroalgae in Antarctica. ISME J. 2013;7:1434-1451.

[4] Godinho VM, Gonçalves VN, Santiago IF, et al. Diversity and bioprospection of fungal community present in oligotrophic soil of continental Antarctica. Extremophiles. 2015;19:585-596.

[5] Henríquez $M$, Vergara $K$, Norambuena J, et al. Diversity of cultivable fungi associated with Antarctic marine sponges and screening for their antimicrobial, antitumoral and antioxidant potential. World J Microbiol Biotechnol. 2014;30:65-76.

[6] Cavicchioli R, Charlton T, Ertan $H$, et al. Biotechnological uses of enzymes from psychrophiles. Microb Biotechnol. 2011;4:449-460.

[7] Krishnan A, Alias AS, Wong CMVL, et al. Extracellular hydrolase enzyme production by soil fungi from King George Island, Antarctica. Polar Biol. 2011;34: 1535-1542.

[8] Cavicchioli R, Siddiqui KS, Andrews D, et al. Low-temperature extremophiles and their applications. Curr Opin Biotechnol. 2002;13:253-261.

[9] Marx JC, Collins T, D'Amico S, et al. Cold-adapted enzymes from marine Antarctic microorganisms. Mar Biotechnol. 2007;9:293-304.

[10] Margesin R, Miteva V. Diversity and ecology of psychrophilic microorganisms. Res Microbiol. 2011;162: 346-361.

[11] Pesciaroli C, Cupini F, Selbmann L, et al. Temperature preferences of bacteria isolated from seawater collected in Kandalaksha Bay, White Sea, Russia. Polar Biol. 2012;35:435-445.

[12] Carrasco M, Rozas JM, Barahona S, et al. Diversity and extracellular enzymatic activities of yeasts isolated from King George Island, the sub-Antarctic region. BMC Microbiol. 2012;12:251.

[13] Carrasco M, Villarreal P, Barahona S, et al. Screening and characterization of amylase and cellulase activities in psychrotolerant yeasts. BMC Microbiol. 2016;16:2.

[14] Connell L, Redman R, Craig S, et al. Diversity of soil yeasts isolated from South Victoria Land, Antarctica. Microb Ecol. 2008;56:448-459.

[15] Ferrari BC, Zhang CD, Dorst J. Recovering greater fungal diversity from pristine and diesel fuel contaminated sub Antarctic soil through cultivation using both a high and a low nutrient media approach. Front Microbio. 2011;2:1-14.
[16] Rao S, Chan Y, Lacap DC, et al. Low-diversity fungal assemblage in an Antarctic Dry Valleys soil. Polar Biol. 2012;35:567-574.

[17] Alias SA, Smykla J, Ming $\mathrm{CH}$, et al. Diversity of microfungi in ornithogenic soils from Beaufort Island, continental Antarctic. CPR. 2013;3:144-156.

[18] Duarte AWF, Dayo-Owoyemi I, Nobre FS, et al. Taxonomic assessment and enzymes production by yeasts isolated from marine and terrestrial Antarctic samples. Extremophiles. 2013;17:1023-1035.

[19] Frate GD, Caretta G. Fungi isolated from Antarctic material. Polar Biol. 1990;11:1-7.

[20] Yu NH, Kim JA, Jeong $\mathrm{MH}$, et al. Diversity of endophytic fungi associated with bryophyte in the maritime Antarctic (King George Island). Polar Biol. 2014;37:27-36.

[21] Zhang $T$, Xiang $H B$, Zhang $Y Q$, et al. Molecular analysis of fungal diversity associated with three bryophyte species in the Fildes Region, King George Island, maritime Antarctica. Extremophiles. 2013;17: 757-765.

[22] Rosa LH, Vaz ABM, Caligiorne RB, et al. Endophytic fungi associated with the Antarctic Grass Deschampsia antarctica Desv. (Poaceae). Polar Biol. 2009;32:161-167.

[23] Rosa LH, Vieira LMA, Santiago IF, et al. Endophytic fungi community associated with the dicotyledonous plant Colobanthus quitensis (Kunth) Bartl. (Caryophyllaceae) in Antarctica. FEMS Microbiol Ecol. 2010;73:178-189.

[24] Santiago IF, Rosa CA, Rosa LH. Endophytic symbiont yeasts associated with the Antarctic angiosperms Deschampsia antarctica and Colobanthus quitensis. Polar Biol. 2017:40:177-183.

[25] Duarte AWF, Passarini MR, Delforno TP, et al. Yeasts from macroalgae and lichens that inhabit the South Shetland Islands, Antarctica. Environ Microbiol Rep. 2016;8:874-886.

[26] Santiago IF, Soares MA, Rosa CA, et al. Lichensphere: a protected natural microhabitat of the nonlichenised fungal communities living in extreme environments of Antarctica. Extremophiles. 2015;19: 1087-1097.

[27] Barahona S, Yuivar Y, Socias G, et al. Identification and characterization of yeasts isolated from sedimentary rocks of Union Glacier at the Antarctica. Extremophiles. 2016;20:479-491.

[28] Onofri S, Fenice M, Cicalini AR, et al. Ecology and biology of microfungi from Antarctic rocks and soils. Ital J Zool. 2000;67:163-167.

[29] Hughes KA, Lawley B. A novel Antarctic microbial endolithic community within gypsum crusts. Environ Microbiol. 2003;5:555-565.

[30] Arenz BE, Blanchette RA. Investigations of fungal diversity in wooden structures and soils at historic sites on the Antarctic Peninsula. Can J Microbiol. 2009;55:46-56.

[31] Held BW, Jurgens JA, Duncan SM, et al. Assessment of fungal diversity and deterioration in a wooden structure at New Harbor, Antarctica. Polar Biol. 2006;29:526-531. 
[32] Gonçalves VN, Campos LS, Melo IS, et al. Penicillium solitum: a mesophilic, psychrotolerant fungus present in marine sediments from Antarctica. Polar Biol. 2013;36:1823-1831.

[33] Vaz ABM, Rosa LH, Vieira ML, et al. The diversity, extracellular enzymatic activities and photoprotective compounds of yeasts isolated in Antarctica. Braz J Microbiol. 2011;43:937-947.

[34] Vaca I, Faúdez C, Maza F, et al. Cultivable psychrotolerant yeasts associated with Antarctic marine sponges. World J Microbiol Biotechnol. 2013;29: 183-189.

[35] Furbino LE, Godinho VM, Santiago IF, et al. Diversity patterns, ecology and biological activities of fungal communities associated with the endemic macroalgae across the Antarctic peninsula. Microb Ecol. 2014;67:775-787.

[36] Loque CP, Medeiros AO, Pellizzari FM. Fungal community associated with marine macroalgae from Antarctica. Polar Biol. 2010;33:641-648.

[37] Gonçalves VN, Vaz ABM, Rosa CA, et al. Diversity and distribution of fungal communities in lakes of Antarctica. FEMS Microbiol Ecol. 2012;82:459-571.

[38] Edgington S, Thompson E, Moore D, et al. Investigating the insecticidal potential of Geomyces (Myxotrichaceae: Helotiales) and Mortierella (Mortierellacea: Mortierellales) isolated from Antarctica. SpringerPlus. 2014;3:289.

[39] Arenz BE, Held BW, Jurges JA, et al. Fungal diversity in soils and historic wood from the Ross sea region of Antarctica. Soil Biol Biochem. 2006;38:3057-3064.

[40] Selbmann L, Onofri S, Zucconi L, et al. Distributional records of Antarctic fungi based on strains preserved in the Culture Collection of Fungi from Extreme Environments (CCFEE) Mycological Section associated with the Italian National Antarctic Museum (MNA). MC. 2015;10:57-71.

[41] Tsuji M, Fujiu S, Xiao $N$, et al. Cold adaptation of fungi obtained from soil and lake sediment in the Skarvsnes ice-free area, Antarctica. FEMS Microbiol Lett. 2013;346:121-130.

[42] Goto S, Sugiyama J, lizuka H. A taxonomic study of Antarctic yeasts. Mycologia. 1969;61:748-774.

[43] Vishniac HS, Onofri S. Cryptococcus antarcticus var. circumpolaris var. nov., a basidiomycetous yeast from Antarctica. Antonie Van Leeuwenhoek. 2003;83: 231-233.

[44] Liu XZ, Wang QM, Goker M, et al. Towards an integrated phylogenetic classification of the Tremellomycetes. Stud Mycol. 2015;81:85-147.

[45] Wang QM, Yurkov AM, Goker M, et al. Phylogenetic classification of yeasts and related taxa within Pucciniomycotina. Stud Mycol. 2015;81:149-189.

[46] Dreesens LL, Lee CK, Cary C. The distribution and identity of edaphic fungi in the McMurdo Dry valleys. Biology (Basel). 2014;3:466-483.

[47] Cox F, Newsham KK, Bol R, et al. Not poles apart: Antarctic soil fungal communities show similarities to those of the distant Arctic. Ecol Lett. 2016;19: 528-536.

[48] Laich F, Vaca I, Chávez R. Rhodotorula portillonensis $\mathrm{sp}$. nov., a bassidiomycetous yeast isolated from
Antarctic shallow-water marine sediment. Int J Syst Evol Microbiol. 2013;63:3884-3891.

[49] Zhang T, Zhang YQ, Liu HY, et al. Cryptococcus fildesensis sp. nov., a psycrophilic basidiomycetous yeast isolated from Antarctic moss. Int J Syst Evol Microbiol. 2014;64:675-679.

[50] Laich F, Chávez R, Vaca I. Leucosporidium escuderoi f.a., sp. nov., a basidiomycetous yeast associated with an Antarctic marine sponge. Anton Van Leeuwenhoek. 2014;105:593-601.

[51] Selbmann L, Turchetti B, Yurkov A, et al. Description of Taphrina antarctica f.a. sp. nov., a new anamorphic ascomycetous yeast species associated with Antarctic endolithic microbial communities and transfer of four lalaria species in the genus Taphrina. Extremophiles. 2014;18:707-721.

[52] Turchetti B, Selbmann L, Blanchette RA, et al. Cryptococcus vaughanmartiniae sp. nov. and Cryptococcus onofrii sp. nov.: two new species isolated from worldwide cold environments. Extremophiles. 2015;19:149-159.

[53] Tsuji M, Tsujimoto M, Imura S. Cystobasidium tubakii and Cystobasidium ongulense, new basidiomycetous yeast species isolated from East Ongul Island, East Antarctica. Mycoscience. 2017;2:103-110.

[54] De Menezes GC, Godinho VM, Porto BA, et al. Antarctomyces pellizariae sp. nov., a new, endemic, blue, snow resident psychrophilic ascomycete fungus from Antarctica. Extremophiles. 2017;21:259-269.

[55] Feller G. Psychrophilic Enzymes: from folding to function and biotechnology. Scientifica (Cairo). 2013;2013: $1-28$.

[56] Gocheva YG, Tosi S, Krumova ET, et al. Temperature downshift induces antioxidant response in fungi isolated from Antarctica. Extremophiles. 2009;13: 273-281.

[57] Margesin R, Feller G, Gerday C, et al. Cold-adapted microorganisms: adaptation strategies and biotechnological potential. In: Bitton, editor. The encyclopedia of environmental microbiology. New York (NY): Wiley; 2002. p. 871-885.

[58] Feller G, Gerday C. Psychrophilic enzymes: hot topics in cold adaptation. Nat Rev Microbiol. 2003;1: 200-208.

[59] Gerday C, Aittaleb M, Bentahir M, et al. Cold-adapted enzymes: from fundamentals to biotechnology. Trends Biotechnol. 2000;18:103-107.

[60] Siddiqui KS, Cavicchioli R, Cold-adapted enzymes. In: Pandey A, Webb C, Soccol CR, et al., editors. Enzyme technology. New York (NY): Springer Science; 2006. p. 615-638.

[61] Ramli ANM, Mahadi NM, Shamsir MS, et al. Structural prediction of a novel chitinase from the psychrophilic Glaciozyma antarctica PI12 and an analysis of its structural properties and function. J Comput Aided Mol Des. 2012;26:947-961.

[62] Ramli ANM, Azhar MA, Shamsir MS, et al. Sequence and structural investigation of a novel psychrophilic $\alpha$-amylase from Glaciozyma antarctica PI12 for coldadaptation analysis. J Mol Model. 2013;19:3369-3383.

[63] De Mot R, Verachtert H. Purification and characterization of extracellular alpha-amylase and glucoamylase 
from the yeast Candida antarctica CBS 6678. Eur J Biochem. 1987; 164:643-654.

[64] Gao B, Mao Y, Zhang L, et al. A novel saccharifying $\alpha$-amylase of Antarctic psychotolerant fungi Geomyces pannorum: gene, cloning, functional expression, and characterization. Starch/Stärke. 2016; 67:1-9.

[65] Azhar MAB. Cloning, expression and analysis of $\alpha$-amylase gene from psychrophilic yeast Leucosporidium antarcticum PI12 [master's thesis]. Malaysia: Universiti Teknologi Malaysia; 2012.

[66] Wang N, Jiane Z, Kaili M, et al. Production of coldadapted cellulase by Verticillium sp. isolated from Antarctic soils. Electron J Biotechnol. 2013;3:1-10.

[67] Fenice M, Selbmann L, Di Giambattista R, et al. Chitinolytic activity at low temperature of an Antarctic strain (A3) of Verticillium lecanii. Res Microbiol. 1998;149:289-300.

[68] Ramli ANM, Mahadi NM, Rabu A, et al. Molecular cloning, expression and biochemical characterization of a cold-adapted novel recombinant chitinase from Glaciozyma antarctica PI12. Microb Cell Fact. 2011;10:94.

[69] Song C, Liu GL, Xu JL, et al. Purification and characterization of extracellular $\beta$-galactosidase from the psychrotolerant yeast 17-1 isolated from sea sediment in Antarctica. Proc Biochem. 2010;45:954-960.

[70] Turkiewicz M, Pazgier M, Donachie SP, et al. Invertase and $\alpha$-glucosidase production by the endemic Antarctic marine yeast Leucosporidium antarcticum. Pol Polar Red. 2005;26:125-136.

[71] Rovati Jl, Pajot HF, Ruberto L, et al. Polyphenolic substrates and dyes degradation by yeasts from 25 de Mayo/King George Island (Antarctica). Yeast. 2013;30:459-470.

[72] Florczak T, Darochb $M$, Wilkinson $M C$, et al. Purification, characterisation and expression in Saccharomyces cerevisiae of LipG7 an enantioselective, cold-adapted lipase from the Antarctic filamentous fungus Geomyces sp. P7 with unusual thermostability characteristics. Enzyme Microb Technol. 2013;53:18-24.

[73] Duarte AWF, Lopes AM, Molino JVD, et al. Liquid-liquid extraction of lípase produced by psychrotrophic yeast Leucosporidium scottii L117 using aqueous two-phase systems. Sep Purif Technol. 2015;156:215-225.

[74] Tsuji M, Yokota Y, Shimohara K, et al. An application of wastewater treatment in a cold environment and stable lipase production of Antarctic Basidiomycetous Yeast Mrakia blollopis. PLoS One. 2013;8:e59376.

[75] Bradner JR, Bell PJ, Teo VS, et al. The application of PCR for the isolation of a lipase gene from the genomic DNA of an Antarctic microfungus. Curr Genet. 2003;44:224-230.

[76] Mohammed S, Te'o J, Nevalainen H. A gene encoding a new cold-active lipase from an Antarctic isolate of Penicillium expansum. Curr Genet. 2013;59:129-137.

[77] Bradner JR, Gillings M, Nevalainen KMH. Qualitative assessment of hydrolytic activities in antarctic microfungi grown at different temperatures on solid media. World J Microbiol Biotechnol. 1999;15: 131-132.

[78] Pavlova K, Garvova S, Hristozova T, et al. Phytase from Antarctic yeast strain Cryptococcus laurentii AL27. Folia Microbiol (Praha). 2008;53:29-34.

[79] Yu P, Wang XT, Liu JW. Purification and characterization of a novel cold-adapted phytase from Rhodotorula mucilaginosa strain JMUY14 isolated from Antarctic. J Basic Microbiol. 2015;55:1029-1039.

[80] Ray MK, Devi KU, Kumar GS, et al. Extracellular protease from the Antarctic yeast Candida humicola. Appl Environ Microbiol. 1992;58:1918-1923.

[81] Lario LD, Chaud L, Almeida MG, et al. Production, purification and characterization of extracellular acid protease from the marine Antarctic yeast Rhodotorula mucilaginosa L7. Fungal Biol. 2015;119:1129-1136.

[82] Nascimento TCES, Sena AR, Gomes JEG, et al. Extracelular serine proteases by Acremonium sp. L1$4 \mathrm{~B}$ isolated from Antarctica: overproduction using cactus pear extract with reponse surface methodology. Biocatal Agric Biotechnol. 2015;4:737-744.

[83] Pazgier $M$, Turkiewics $M$, Lalinowska $H$, et al. The unique cold-adapted extracellular subtilase from phychrophilic Leucosporidium antarticum. JMC B. 2003;21:39-42.

[84] Abrashev R, Feller G, Kostadinova $N$, et al. Production, purification, and characterization of a novel cold-active superoxide dismutase from the Antarctic strain Aspergillus glaucus 363. Fungal Biol. 2016;120:679-689.

[85] Kasieczka-Burnecka M, Kuc K, Kalinowska H, et al. Purification and characterization of two cold-adapted extracellular tannin acyl hydrolases from an Antarctic strain Verticillium sp. P9. Appl Microbiol Biotechnol. 2007;77:77-89.

[86] Del-Cid A, Ubilla P, Rayanal MC, et al. Cold-active xylanase produced by fungi associated with Antarctic marine sponges. Appl Biochem Biotechnol. 2014;172:524-532.

[87] Gomes J, Gomes I, Steiner W. Thermolabile xylanase of the Antarctic yeast Cryptococcus adeliae: production and properties. Extremophiles. 2000;4:227-235.

[88] Passarini MRZ, Santos C, Lima N, et al. Filamentous fungi from the Atlantic marine sponge Dragmacidon reticulatum. Arch Microbiol. 2013;195:99-111.

[89] Duncan SM, Farrell RL, Thwaites JM, et al. Endoglucanase-producing fungi isolated from Cape Evans historic expedition hut on Ross Island, Antarctica. Environ Microbiol. 2006;8:1212-1219.

[90] Duncan SM, Minaki R, Farrell RL, et al. Screening fungi isolated from historic Discovery Hut on Ross Island, Antarctica for cellulose degradation. Antarct Sci. 2008;20:463-470.

[91] Ludley KE, Robinson CH. 'Decomposer' Basidiomycota in Arctic and Antarctic ecosystems. Soil Biol Biochem. 2008;40:11-29.

[92] Arenz BE, Held BW, Jurges JA, et al. Fungal colonization of exotic substrates in Antarctica. Fungal Divers. 2011;49:13-22.

[93] Held BW, Blanchette RA. Deception Island, Antarctica, harbors a diverse assemblage of wood decay fungi. Fungal Biol. 2017;121:145-157. 
[94] Tsuji M, Yokota Y, Kudoh S, et al. Improvement of direct ethanol fermentation from woody biomasses by the Antarctic basidiomycetous yeast Mrakia blollopis, under a low temperature condiction. Cryobiology. 2014;68:303-305.

[95] Souza TV, Araujo JN, Silva VM, et al. Chemical stability of a cold-active cellulase with high tolerance toward surfactants and chaotropic agent. Biotechnol Rep (Amst). 2016;9:1-8.

[96] Wang Y, Gao C, Zheng Z, et al. Immobilization of cold-active cellulose from Antarctic bacterium and its use for kelp cellulose ethanol fermentation. BioResources. 2015;10:1757-1772.

[97] Mahaeana AK, Ray P. Optimization and characterization of cold-active endoglucanase produced by Aspergillus terreus strain AKM-F3 grown on sugarcane bagasse. Turk J Biol. 2015;39:175-185.

[98] Petrescu I, Lamotte-Brasseur J, Chessa JP, et al. Xylanase from the psychrophilic yeast Cryptococcus adeliae. Extremophiles. 2000;4:137-144.

[99] Fenice M, Selbmann L, Zucconi L, et al. Production of extracellular enzymes by Antarctic fungal strains. Polar Biol. 1997; 17:275-280.

[100] Divya K, Padma PN. Use of Plackett-Burman design for rapid screening of diverse raw pectin sources for cold-active polygalacturonase and amylase production by Geotrichum sp. Int J Curr Microbiol App Sci. 2015;4:821-827.

[101] Barghini P, Moscatelli D, Garzillo AMV, et al. High production of cold-tolerant chitinases on shrimp wastes in bench-top bioreactor by the Antarctic fungus Lecanicillium muscarium CCFEE 5003: Bioprocess optimization and characterization of two main enzymes. Enzyme Microb Technol. 2013;53:331-338.

[102] Fenice M, Barghini P, Selbmann L. Combined effects of agitation and aeration on the chitinolytic enzymes production by the Antarctic fungus Lecanicillium muscarium CCFEE 5003. Microb Cell Fact. 2012;11:12.

[103] Fenice $M$. The psychrotolerant Antarctic fungus Lecanicillium muscarium CCFEE 5003: a powerful producer of cold-tolerant chitinolytic enzymes. Molecules. 2016;21:447.

[104] Fenice M, Gooday GW. Mycoparasitic actions against fungi and oomycetes by a strain (CCFEE 5003) of the fungus Lecanicillium muscarium isolated in Continental Antarctica. Ann Microbiol. 2006;56:1-6.

[105] Peterson R, Kautto L, Sluyter SV, et al. In search of clarity: do cold-active proteases from Antarctic fungi provide alternatives to heat-stabilisation with bentonite? Wine and Viticulture J. 2013;28:20-23.

[106] Chaud L, Lario LD, Bonugli-Santos RC, et al. Improvement in extracellular protease production by the marine antarctic yeast Rhodotorula mucilaginosa L7. New Biotechnol. 2016;33:807-814.

[107] Turkiewicz M, Pazgier M, Kalinowska $H$, et al. A coldadapted extracellular serine proteinase of the yeast Leucosporidium antarcticum. Extremophiles. 2003;7: 435-442.

[108] Margesin R, Dieplinger H, Hofmann J, et al. A coldactive extracellular metalloprotease from Pedobacter cryoconitis-production and properties. Res Microbiol. 2005;156:499-505.
[109] Margesin R. Potential of cold-adapted microorganisms for bioremediation of oil-polluted Alpine soils. Int Biodeterior Biodegrad. 2000;46:3-10.

[110] Russell NJ. Cold adaptation of microorganisms. Philos Trans R Soc Lond B Biol Sci. 1990;326:595-611.

[111] Florczak T, Makowski K, Turkiewicz M. The coldadapted lipase of an Antarctic fungus Beauveria sp. P7 as an effective catalyst of enantioselective 1-phenylethanol trasesterification. J Biotech. 2007;131:S89-S90.

[112] Loperena L, Soria V, Varela $H$, et al. Extracellular enzymes produced by microorganisms isolated from maritime Antarctica. World J Microbiol Biotechnol. 2012;28:2249-2256.

[113] Yang JK, Liu LJ, Dai JH, et al. de novo design and synthesis of Candida antarctica lipase $\mathrm{B}$ gene and $\alpha$-factor leads to high-level expression in Pichia pastoris. PLoS One. 2013;8:e53939.

[114] Struvay C, Feller G. Optimization to low temperature activity in psychrophilic enzymes. Int J Mol Sci. 2012;13:11643-11665.

[115] Joseph B, Ramteke PW, Thomas G. Cold active microbial lipases: some hot issues and recent developments. Biotechnol Adv. 2008;26:457-470.

[116] Tsuji M, Yokota Y, Kudoh S, et al. Comparative analysis of milk fat decomposition activity by Mrakia spp. isolated from Skarvsnes ice-free area, East Antarctica. Cryobiology. 2015;70:293-296.

[117] Watanabe Y, Shimada Y, Sugihara A, et al. Continuous production of biodiesel fuel from vegetable oil using immobilized Candida antarctica lipase. J Amer Oil Chem Soc. 2000;77:355-360.

[118] Singh SM, Singh PN, Singh SK, et al. Pigment, fatty acid and extracellular enzyme analysis of a fungal strain Thelebolus microspores from Larsemann Hills, Antarctica. Pol Rec. 2014;50:31-36.

[119] Kuddus M, Saima R, Ahmad IZ. Cold-active extracellular a-amylase production from novel bacteria Microbacterium foliorum GA2 and Bacillus cereus GA6 isolated from Gangotri glacier, Western Himalaya. J Genet Eng Biotechnol. 2012;10:151-159.

[120] Zhang X, Hua M, Song C, et al. Occurrence and diversity of marine yeasts in Antarctica environments. J Ocean Univ China. 2012;11:70-74.

[121] Yao J, Guo GS, Ren GH, et al. Production, characterization and applications of tannase. J Mol Catal B Enzym. 2014;101:137-147.

[122] Parvizpour S, Razmara J, Ramli ANM, et al. Structural and functional analysis of a novel psychrophilic $\beta$-mannanase from Glaciozyma antarctica PI12. J Comput Aided Mol Des. 2014;28:685-698.

[123] Verma AK, Raghukumar C, Verma P, et al. Four marine-derived fungi for bioremediation of raw textile mill effluents. Biodegradation. 2010;21:217-233.

[124] Litova K, Gerginova M, Peneva N, et al. Growth of Antarctic fungal strains on phenol at low temperatures. J BioSci Biotech. 2014;1:43-46.

[125] Gerginova MG, Peneva NM, Krumova ET, et al. Biodegradation ability of fungal strains isolated from Antarctic towards pah. In Proceedings of the 13th International Conference of Environmental Science and Technology; Sept 5-7; Athens, Greece. 2013. p. 1-9. 
[126] Tosi S, Kostadinova N, Krumova E, et al. Antioxidant enzyme activity of filamentous fungi isolated from Livingston Island, Maritime Antarctica. Polar Biol. 2010;33:1227-1237.

[127] Mao Y, Yina $Y$, Zhanga $L$, et al. Development of a novel Aspergillus uracil deficient expression system and its application in expressing a coldadapted -amylase gene from Antarctic fungi Geomyces pannorum. Process Bioch. 2015;50: 1581-1590.

[128] Larsen MW, Bornscheuer UT, Hult K. Expression of Candida antarctica lipase B in Pichia pastoris and various Escherichia coli systems. Protein Expr Purif. 2008;62:90-97.
[129] Alias N, Mazian MA, Salleh AB, et al. Molecular cloning and optimization for high level expression of cold-adapted serine protease from antarctic yeast Glaciozyma antarctica PI12. Enzyme Res. 2014;2014:20.

[130] Koleva L, Pishtiyski I, Pavlova K. Purification and properties of extracellular $\beta$-glucosidase from the Antarctic yeast strain Cryptococcus albidus AL3. Bulg J Agric Sci. 2006;12:713-720.

[131] Lario LD, Malpiedi JP, Pereira JFB, et al. Liquid-liquid extraction of protease from cold-adapted yeast Rhodotorula mucilaginosa L7 using biocompatible and bidegradable aqueous two-phase systems. Sep Sci Technol. 2016;51:57-67. 